\title{
Financial Aid and Student Dropout in Higher Education: A Heterogeneous Research Approach
}

\author{
Rong Chen
}

\section{Introduction}

Over the past several decades, a large body of research has studied student outcomes in higher education. Among them, many examined the relationships between financial aid and student dropout behavior. But this line of research focuses primarily on the effects of financial aid in general, paying limited attention to the differences in dropout behavior across socioeconomic and racial/ethnic groups and how financial aid influences these gaps.

In this chapter, I argue that it is important to consider the economic and racial/ ethnic diversity of students when evaluating the effects of financial aid on student dropout. Given the heterogeneous nature of the student population, researchers in higher education need to explore the possible variations in aid effects on dropout risks across different subgroups rather than just specify average effects for the population as a whole. To achieve this goal, a comprehensive conceptual framework and a more appropriate analytic approach are needed. In addition, since St. John et al.'s (2000) extensive review of the economic influence on persistence research, an updated review of this line of research will help us continue to re-conceptualize student departure models from an economic perspective. In this chapter, I develop an alternative approach for investigating the differential effects of financial aid on student departure risks by integrating economic theories with theoretical frameworks from other disciplines. This heterogeneous approach pays particular attention to the role that financial aid plays in reducing dropout risk gaps across income and racial/ ethnic groups.

The chapter first describes the importance of examining the variation in the effects of aid on student departure. It then reviews and critiques various theoretical approaches, particularly the economic approach, for examining student dropout risk. Third, although prior empirical studies and methodologies have generally promoted a better understanding of how financial aid affects student departure, they are nevertheless limited. This chapter highlights some of the merits and limitations of prior persistence/dropout literature, and provides a few suggestions for future research. Third, by expanding Heller's (1997) notion of price-demand, the chapter imports three economic concepts-liquidity constraints, price elasticity, and debt 
aversion-and based on these concepts, introduces two hypotheses for use in the analysis of differential aid effects. Finally, the chapter presents a comprehensive conceptual framework and an alternative analytic approach for evaluating financial aid effects in future student dropout research.

\section{The Importance of Investigating Differential Aid Effects on College Dropout Risks}

\section{Policy Background}

Research in the United States has established that investment in higher education is beneficial to individuals (Berger, 1992; Perna, 2003), society (Bowen, 1997), and economic development (Bowen, 1997; Paulsen, 1998), and also reduces inequality in human conditions (Anderson \& Hearn, 1992; Bowen, 1997; Park, 1996). Given the benefits of higher education, equal access to and attainment in colleges and universities has become a centerpiece of public policy toward higher education. In the 1960s, the federal government became extensively involved in student financial aid, aiming to offer equal educational opportunities to students, regardless of their economic status (McPherson \& Schapiro, 1998). The three most common types of student financial aid are grants, loans, and work-study. Overall, financial aid, especially grants for needy students, has been an important resource for equalizing higher education opportunities. The last two decades, however, have witnessed a dramatic shift in college student funding from grants to loans, a decline in the purchasing power of the maximum Pell award (College Board, 2005a), and increasing tuition (College Board, 2005b).

Equal education is an important goal to be realized as the gaps between wealthy and poor in educational attainment still exist. For instance, among first-time freshmen who entered college during the 1995-1996 academic year, 56\% of students from high-income families attained a bachelor's degree, while only $26 \%$ of low-income peers did the same (National Center for Education Statistics, 2003). These statistics provide evidence that problems of equity still persist for those from the lower socioeconomic classes. In addition, the increased popularity of state merit aid, which is distributed disproportionately to wealthier students, the increased use of merit-based relative to need-based grants in institutional aid awards, as well as revisions to the financial aid formula that opened the subsidized loan program to more affluent families, tend to exacerbate the equity problem (Dowd, 2004; Heller \& Marin, 2002; McPherson \& Schapiro, 2002).

In addition to the concern about inequality in educational attainment across income groups, another important issue that challenges educational equality is the racial/ethnic disparity in college outcomes. Overall, although the number of bachelor's degrees awarded to minority students has increased in the past decade, minority students are consistently under represented among bachelor's degree recipients 
(Nettles \& Perna, 1997; Perna, 2000). African Americans and Hispanics made up only $7.0 \%$ and $4.2 \%$, respectively, among those who attained a bachelor's degree, while they represented $14.3 \%$ and $13.7 \%$ of the college-age population in the nation (Perna, 2000). In addition, minority students are found to be more sensitive to prices and less willing to use educational loans (Kaltenbaugh et al., 1999; St. John, 1991). The continuing financing changes will likely imperil the economic and social well-being of minority students since they have a disproportionately negative effect on the educational attainment of minority students (Hu \& St. John, 2001). Further understanding of the influence of financial aid awards on dropout by race/ ethnicity can help inform policymakers and institutional administrators about strategies that can promote educational opportunity for these historically disadvantaged students.

\section{Purpose of the Chapter}

There has been an increasing concern about the socioeconomic and racial/ethnic gaps in student dropout, but many studies in this field has been subject to several conceptual and methodological limitations, including insufficient consideration of the socioeconomic and racial/ethnic discrepancies in student outcomes, and limited studies for understanding the role that different types and amounts of aid play in reducing these gaps (Chen \& DesJardins, 2008).

Given the persistent inequality in college student dropout risk, and the lack of research as to whether and how these gaps due to income and racial/ethnic differences can be narrowed, studies to further our understanding as to why student dropout patterns differ markedly between disadvantaged students and their better-off peers are in great need. Instead of repeatedly describing the continuing disparities in educational attainment, we need to focus on what specifically might be done to improve this condition. Research comparing students from different socioeconomic and racial/ethnic backgrounds in their responsiveness to various financial aid programs can be helpful for meeting this need. Thus, an alternative approach to evaluating financial aid effects on student dropout risks is crucial. It would also be very timely considering the wavering commitments to equal opportunities by the federal and state governments, and the debates in recent years over diversity in postsecondary education in American society (McPherson \& Schapiro, 1998; Slaughter \& Leslie, 1997).

Because of the large differences in student dropout rates between two-year and four-year institutions, and the fact that many students who attend two-year institutions do not have degree completion as their ultimate goal, this chapter focuses on dropout behavior in four-year institutions only. In addition, prior studies and related literature have often not differentiated between persistence and departure (Berger \& Braxton, 1998; Cabrera et al., 1992a; Elkins et al., 2000; Milem \& Berger, 1997; Moline, 1987; Pascarella \& Chapman, 1983; Tinto, 1992). I therefore include in this review several persistence studies that have consequences for student departure research. 


\section{Theoretical Approaches to Examining College Student Departure}

Five major theories are widely used for studying student departure: psychological, sociological, organizational, interactionalist, and economic theories (Braxton \& Hirschy, 2005; Tinto, 1992). Generally, the psychological approach emphasizes the impact of individual psychological attributes in the process of dropout; sociological and economic approaches focus more on the broader external social and economic forces; organizational theory regards student departure as affected by immediate organizational features; and interactionalist theories stress the role of both individual and environmental forces.

\section{Psychological Theories}

Psychological theories view student departure as primarily influenced by attributes reflecting an individual's psychological characteristics. Personal characteristics, such as intellectual attributes or level of maturity, can be important in shaping a student's academic ability or affecting their motivation in academic study, which in turn influences the individual's departure behavior (Heibrun, 1965; Rossmann \& Kirk, 1970; Summerskills, 1962). There are four major sub-theories for explaining persistence/dropout behavior (Bean \& Eaton, 2000): attitude-behavior theory, the coping behavioral approach theory, self-efficacy theory and the attrition theory. Attitude behavior theory provides an overall structure for this line of research. The coping behavioral approach emphasizes a person's adaptation ability in a new environment. Self-efficacy theory stresses an individual's self-perception as capable of dealing with specific situations. And attribution theory focuses on whether an individual has a strong sense of internal locus of control. Based on these theories, scholars use several factors as predictors of student departure behavior, including intentions to stay, students' feelings about their adaptations to the environment, and the motivational component of academic and social integration.

Psychological theories of student departure, regardless of their particular focus, share the common view that departure is primarily a reflection of an individual's psychological response to the environment, and largely due to a student's personal ability or willingness to persist in college. This perspective contributes to the departure research in that it reveals an individual's internal factors that influence a student's decision to persist or depart. But by viewing persistence/dropout as primarily the consequence of individual students' internal strengths or weaknesses, this perspective fails to account for the important role played by external factors (Tinto, 1992).

\section{Sociological Theories}

In contrast to the more individual perspective of the psychological theories, sociological theories treat students' dropout decisions as a consequence of the social attributes of individuals, institutions, and society. Some of the important attributes 
include socio-economic status, race/ethnicity, and opportunity structure that describe the individual's and the institution's place in the broader hierarchy of society (Tinto, 1992). Theories from the sociological perspective can be categorized into three groups: conflict theory (Clark, 1960), social reproduction theory (Bourdieu, 1973, 1977), and social attainment theory (Duncan et al., 1972; Featherman \& Hauser, 1978). They all argue that, although individual skills and abilities are important in predicting students' dropout decisions, social and cultural capital as well as the greater process of social stratification is more central. In particular, proponents of social attainment theory (Duncan et al., 1972; Featherman \& Hauser, 1978) maintain that family socioeconomic statuses influence children's educational and occupational attainment, which provide a theoretical foundation for the investigation of socio-economic stratification in higher education.

Sociological theories of student departure remedy the deficiencies of psychological theories by regarding the process of student attrition as the consequence of larger social stratification. The theories are useful for describing how broad social forces may impact student departure, but an over-emphasis on the role of external forces limits opportunities to explain the psychological and institutional attributes that might have an impact on the process of student departure.

\section{Organizational Theories}

Organizational theories are concerned with the impact of the college environment forces on student behavior (Berger \& Milem, 2000). Compared to the psychological and sociological theories, which focus on the effects of individual and social factors, organizational theories assume that student dropout is analogous to turnover in the work-place. The organizational attributes of higher educational institutions, such as structure, size, faculty-student ratios, and institutional resources, may have a strong effect on students' socialization patterns, and therefore on their departure behavior as well. Bean's $(1980,1983)$ causal model of student attrition, developed from Price's (1977) model of turnover in work organizations, is representative of this group of theories. The major argument of this model is that colleges differ in their structural linkages to occupational and economic groups; hence, their capacity to allocate graduates to high status occupations also varies. Although organizational theories offer a framework for understanding dropout risks across institutions with different characteristics, they are relatively less developed and have been tested by fewer empirical studies.

The organizational perspective on student persistence/departure provides important inputs for understanding how institutional factors may influence student decisions. Nevertheless, it fails to effectively explain the mechanisms by which these factors can eventually affect students' decisions. Tinto (1992) argues that one reason for this failure may be that it does not include lower-level factors, such as students' interactions with peers and faculty, which might mediate the organizational effects of student behavior. More recently, Berger (2000a) has also reiterates that 
organizational theories need to consider individual students instead of concentrating too much on student outcomes at the institutional level through the use of aggregated student information.

\section{Interactionalist Theories}

Interactionalist theories emerged in the 1970s and became well-developed in the 1990s. Rather than simply combining internal or external determinants as the psychological, social, and organizational theories usually do, this approach integrates the above three perspectives and treats the student departure process as reflecting a dynamic interaction between individuals and the environment (Tinto, 1992). It includes informal social organizations, such as student peer groups and classrooms, as well as personal interaction among students, faculty, and staff as important factors influencing student departure.

The early form of the interactionalist view employed the notion of "role socialization" and "personal-role fit" (Rootman, 1972). Later, a more complex and complete form was initiated by Tinto $(1975,1987)$. This new development is an extension of Spady's (1970) work on connecting Durkheim's (1951) theory of suicide to student departure. Its main point is that individual persistence in, and dropout from, institutions of higher education can be viewed as arising out of a longitudinal process of interactions between an individual with given attributes, skills, prior educational experiences, dispositions (intentions and commitments), and other members of the academic and social systems of the institution (Tinto, 1987). Experiences promoting students' social and intellectual integration into college communities are likely to strengthen their commitment and therefore reduce departure risks.

The interactionalist approach provides a more inclusive view of the student departure process by integrating the psychological, social, and organizational perspectives. It emphasizes the impact of dynamic, reciprocal interaction between the environment and individuals, and offers an explicit model for testing hypotheses about student departure. Tinto's interactionalist model is a classic in studying both persistence and departure research, and has been widely tested (Braxton, 2000; Braxton et al., 2004). Two weaknesses, however, must be noted. First, the role of academic and social integration is only partially supported by empirical results. Some have found the effects of social and academic integration to be non-significant (Nora, 1987). Second, interactionalist theories have not sufficiently considered economic factors. Although finances were added later, this model failed to take into account the role of financial aid and tuition price in student persistence (St. John et al., 2000).

The discussions above indicate that the theories from psychological, sociological, organizational, and interactionalist perspectives are complementary, with each one contributing a different insight not offered by the other. While these theories have laid a solid foundation for identifying how various individual, organizational and social factors may influence student decisions, economists have also offered insightful explanations to increase our understanding of how financial factors affect student departure. 


\section{Economic Theories}

Studying persistence/dropout from an economic perspective is a more recent phenomenon. This approach is based on human capital theory (Becker, 1964; Psacharopoulos, 1987), and on supply and demand theory (Radner \& Miller, 1975), and has produced a considerable volume of literature in the last decade or so.

Economists Schultz (1961) and Becker (1964) applied the concept of human capital to suggest that individuals derive economic benefits from investment in education, training, health and nutrition. Individuals can increase their stock of human capital through a variety of training and educational experiences. For higher future monetary and non-monetary returns, they can either choose to attend universities or select a low-paying job with a great learning potential. In each case, investment in human capital leads to higher productivity, which is rewarded by higher future returns. Rational individuals, as economists assume, weigh the expected costs and benefits when deciding to make an investment in human capital, such as higher education (DesJardins \& Toutkoushian, 2005; Paulsen, 2001). From this analysis, each member of society decides whether, and how much, to invest in their own human capital.

Supply and demand is a fundamental concept for the theory of price determination in economics. Supply represents the quantity of a product or service that the market can offer at various prices, while demand represents how much people are able and willing to buy at those prices; the relationship between price and quantity demanded is known as the demand relationship. The correlation between price and how much of a good or service is supplied into the market is known as the supply relationship. Therefore, supply and demand theory suggests that the quantity of a product or service supplied or demanded is related to its price. A core element of this theory is that there is an inverse relationship between price and quantity demanded. When price increases, demand decreases, and vice versa.

Human capital theory contributes to research in student departure in that it treats education as an important investment for bringing in future returns to offset the individual's time, energy and money spent (Becker, 1964). Therefore, in the context of higher education, students' decisions as to whether or not to spend the money and persist are influenced by economic factors. Supply and demand theory justifies the view that college tuition and financial aid can influence student demand for higher education. Thus, similar to any other economic activities, the decision about persistence or departure is just a process for estimating one's payment capability and weighing the costs and benefits of investing one's scarce resources in different ways. Therefore, financial attributes of educational institutions, such as tuition and financial aid, have been incorporated in student departure studies. The assumption is that financial aid reduces net tuition, and therefore influences student dropout decisions.

Early economic theories and models of student persistence/departure examined the effect of finances (e.g., Cabrera et al., 1990; Voorhees, 1985), but factors such as interaction with peers and faculty, which have been shown to be significant in interactionalist departure models, were not sufficiently considered. Although early 
economic models have been criticized for having an incomplete view of student departure, the recent integrative economic models, such as the ability-to-pay model and the college choice-persistence nexus model, have been developed for a new understanding that can inform future research. For example, Cabrera and his associates (Cabrera et al., 1992a, b) viewed persistence as a complex process linking experiences with the institution, cognitive and affective changes, a student's commitments to the institution, and intent to persist. As an advancement of the prior approaches from psychological, social, organizational, and interactionalist perspectives, they added finances into the model to examine the impact of financial aid and college price. The other improvement in the economic approach was made by St. John et al. (1996), who established support for the proposition that there exists a nexus between the college-choice stage and a student's subsequent persistence in college. Financial factors were found to influence both student college choice and persistence. This updated economic approach has not only preserved the major construct of traditional theories and models but also provided a better understanding of student departure. By integrating finances into the interactionalist model and by connecting college choice and persistence, the economic models of student departure have provided a more comprehensive framework for researching student departure behavior. In higher education research, the economic approach has become very important for its ability to provide a rationale for public funding and the underlying rationale for using need-based financial aid to equalize educational opportunity (St. John, 2003).

While theories of human capital and supply and demand provide the foundation for examining financial aid effects, they have not stimulated much research on the differential effects of aid across individual groups in the student dropout process. Findings in the literature help identify the general effects of financial aid on student dropout risks but do not provide sufficient explanations as to why a particular type of aid might be more important to one student group than to another. To explore the differential effects of financial aid on dropout risks, I apply three additional important economic concepts: liquidity constraints, price elasticity, and debt aversion. Illustration of how these economic concepts advance this inquiry of student departure will be elaborated on following the critique of the empirical studies and the methodologies in the next section.

\section{Empirical Research on Student Departure}

Researchers in psychological, social, organizational, interactionalist, and economic approaches have identified a variety of factors that provide evidence for understanding the student departure decision process. Factors include student background characteristics, educational aspiration, pre-college preparation, financial factors and college experience. However, there are some notable limitations in these empirical studies: (1) the limited time perspective, (2) the problems in examining aid effects, (3) the limited attention to socioeconomic gaps, and (4) the lack of consideration of racial/ ethnic group differences. 


\section{Time Perspective}

With few exceptions (Chen \& DesJardins, in press; DesJardins et al., 1999, 2002a; Ishitani \& DesJardins, 2003; St. John et al., 1991), the literature on student persistence/departure adopts a limited time perspective. Researchers generally considers two points in time: the point of entry and the time when dropout is determined (Tinto, 1982). But as Murdock (1987) suggested, studies should measure departure over a longer period of time than just one semester, one year, or even two years, so as to better determine the temporal effects of different factors on student departure.

\section{Examination of Aid Effects}

The literature examining aid effects on student departure also poses several problems. First, the research often takes limited consideration of the longitudinal characteristics of student departure and the possible time-varying effects of aid. Student dropout is a time-dependent process, and treating it as time-constant may constrain researchers from exploring whether, and if so, how student aid effects change over time.

Second, researchers usually use an aggregated variable of financial aid, without accounting for possible differences by subtypes. Due to the unavailability of dollar amounts for the different types of financial aid, some studies simply used a variable representing the total amount of financial aid each year a student receives. This measure took only the total amount of aid into consideration, ignoring the fact that different types of aid might have different effects. Other studies used just one aggregated loan variable, either in dichotomous or total amount format, as a proxy for all types of loans. Intuitively, loans of different types have a different focus and benefits, and should thus weigh differently on students' departure decision. For example, the Perkins loans and Stafford subsidized loans are awarded based on financial need, with interest paid by the federal government during in-school, grace, and deferment periods. In contrast, the Stafford unsubsidized loans, which are non-need-based, require that students pay the interest shortly after receiving the loans. Since these different types of loans have different dollar values, it is reasonable to assume that the need-based loans would help students more than the non-need-based loans in preventing them from dropping out.

Third, interactions between aid and non-aid variables are often neglected, although it is possible that student aid effects may vary among subgroups (e.g., students from different socioeconomic and racial/ethnic backgrounds). For example, loans may help middle- or high-income students to persist and succeed in higher education, while having some loans or excessive loans may not help low-income students at all or may even increase their dropout risks. Treating aid effects as uniform does not allow us to differentiate the effects of financial aid if there are any. 


\section{Attention to the Socioeconomic Gap}

As some scholars have observed (Paulsen \& St. John, 2002; Walpole, 2003), higher education research has given only limited consideration to social class discrepancies in student outcomes. The same holds true for student departure studies. The most common approach that scholars take in departure studies is to control for socioeconomic differences rather than focus on how those differences may be reduced by educational interventions or policies. This omission of social class discrepancies has limited our understanding of the socioeconomic differences in student departure and the role that educational policies/interventions can play in reducing these gaps.

More recently, a few studies have started to take socioeconomic differences as the focus of research (Paulsen \& St. John, 2002; St. John \& Starkey, 1995; Walpole, 2003) by running separate regressions for different income groups and then comparing the coefficients. For example, Paulsen and St. John's (2002) analysis of class differences related to the financial nexus indicates that students from various income backgrounds responded differently to finances. Poor students were more positively influenced by grants, and compared to higher-income students, workingclass students were more negatively affected by inadequate loan and work-study aid.

The studies cited above have significantly promoted our understanding of aid effects by family income, an issue often ignored in the prior literature. Nevertheless, comparison of differences in the coefficients of aid variables across income groups does not indicate the significance of the differential effects of aid. It was not until recently that Dowd (2004) examined the different effects of aid on students from different income groups by testing the significance of the interaction between aid and income. But Dowd's effort was constrained by cross-sectional data, which treats financial aid as time-constant.

\section{Consideration of the Racial/Ethnic Gap}

Although research on racial/ethnic differences in student persistence/departure predates minority students' becoming a critical mass in higher education (Rendon et al., 2000), small sample sizes for minority students limited the early researchers' ability to control for race and to detect racial group differences. Minority students were even excluded from the samples for the same reason. But over the past decade, there has been greater academic interest in minority students (Nora \& Cabrera, 1993), enriching our understanding of departure behavior for them and contributing to public policies promoting equal educational outcomes across racial/ethnic groups. But as with the research on the socioeconomic gap in student departure, models that include race/ethnicity often treat it only as a control factor as a whole without closely examining the diversity within these racial groups, thus failing to test the differential effects of financial aid on student departure for different racial/ethnic groups.

A few student persistence studies, however, have investigated the aid effects by race/ethnicity. Results indicate that, in their persistence decisions, African Americans 
(Hu \& St. John, 2001; St. John et al., 2005) and Hispanics (Hu \& St. John, 2001), compared with their White peers, are more responsive to student aid. In particular, grants and tuition had a substantial influence on persistence for African Americans, while loans were more effective for Whites than for other groups. These findings from persistence studies shed light on future student dropout research.

\section{Methodology}

Over the past three decades, student departure research has not only evolved in terms of theoretical frameworks and empirical investigations but has also gradually developed and improved in its research methodology. Methodological development, particularly the availability of data, new statistical methods, and computer software, has facilitated in-depth studies of student departure.

\section{Data}

A reliable examination of student departure at either the institutional or national level clearly depends on the quality of data. In early times, limited and inappropriate data was a major obstacle for a comprehensive investigation of student departure (Perna, 1998). Usually, data were from institutions or single institutions (Berger \& Milem, 1999; Cabrera et al., 1992a, 1992b; DesJardins et al., 1999; Tinto, 1997). Detailed data at the institutional level about students and the institution allowed researchers to examine in depth what factors determine students' departure from a given institution. But institutional dropout is not the only type of departure behavior, as dropout students may transfer to other institutions. Among those transferred students, some successfully integrate into the new institutions, while others may eventually leave higher education system without returning. To take this latter group of students into account, scholars have started to use data at the national level (Cabrera et al., 1990; Dowd, 2004; Leppel, 2002; Paulsen \& St. John, 2002; St. John et al., 1991).

In addition to the fact that institutional level data do not take into account transfer students, it poses a number of other limitations. First, institutional data are often small in sample size and in the number of dropouts, thus it is likely to cause unstable estimations if small-sample institutional data are used. Second, as Pantages and Creedon (1978) indicated, students from the same institution could be very similar in background, so the effect of socioeconomic status on student departure for the general population may be masked in a single institution study. The third problem is related to the examination of aid effects using single institution data. As proposed in St. John's (1991) literature review, "students in the same institutions are subject to the same tuition charges and the same aid packaging philosophies; therefore there might not be sufficient variation for aid awards to be statistically significant when the influence of student aid is examined at the institutional level" (p. 23). 
McCreight and LeMay (1982) also note that single institutional studies generally report no relationship between the amount of aid and departure due to the lack of variance in students' unmet financial need. Fourth, most institutional studies are limited in time-perspective. Although some use the longitudinal research designs (e.g., Cabrera et al., 1990; Berger \& Milem, 1999), the data are often gathered only at two or three points in time.

\section{Statistical Methods}

Early studies of student departure were constrained by methods available at the time. Initially, they were just descriptive reports of the patterns of departure, using demographic characteristics as sources of variation and providing little information on why students leave. Later, linear regression was applied (e.g., Pascarella \& Terenzini, 1980), but this method failed to capture the dichotomous nature of the outcome variables of persistence/departure (Cabrera et al., 1990; St. John et al., 2000).

Recently, many studies (Cabrera et al., 1990; Leppel, 2002) have resorted to using more complicated analytical techniques, such as logistic regression, to remedy this deficiency. Logistic regression analysis is an appropriate technique for studying attrition because of the dichotomous nature of dropout as the dependent variable. Cabrera et al. (1990) also suggested that logistic regression analysis not only captures the probabilistic distribution embedded in dichotomized distributions but also avoids violating the assumptions of homoscedasticity and functional specification (Becker \& Nelder, 1978; Weiler, 1987). It is worth noting, however, that linear or logistic regression using a static approach does not take into account the effects of financial aid on students' departure over time.

In the early 1990s, scholars (St. John et al., 1991) began to conduct sequential regression analyses, in which they created separate samples for each time period and ran a series of logistic regression models on each sample. This sequential analysis approach is an important step forward by treating student persistence/departure as a longitudinal process, and has contributed to a better understanding of the possible variation of financial aid effects between time intervals. Its limitation, however, lies in the fact that the impact of time on the student outcome was not fully explored and the effects of factors in previous time periods could not be controlled for in the estimation of subsequent outcomes.

More recently, event history modeling has been introduced to consider the temporal nature of student departure (Chen \& DesJardins, in press; DesJardins et al., 1999; DesJardins et al., 2002a; Ishitani \& DesJardins, 2003). This analytic technique has been frequently used in economic and social science research for investigating the occurrence and timing of events (Diggle et al., 1994). As student departure is a longitudinal process, and the factors affecting departure may be time-varying, longitudinal methods are suited to studying student departure. Compared to the logistic regression typically used for cross-sectional data analysis, event history methods have the advantage of being able to examine time effects and time-varying effects of covariates on student departure. 
As DesJardins (2003) suggested, event history methods have been infrequently used in student dropout research for the following several reasons. First, the lack of statistical packages for analyzing longitudinal events has hindered researchers from using this method to study temporal processes. But with the addition of event history modeling to the latest versions of major statistical software packages, technological difficulty has become less of a concern. Secondly, longitudinal data were initially difficult to obtain because of cost and storage considerations. With methodological and technological improvement in data collection, longitudinal data are now much more readily available. Last, but not least, is the fact that this complicated statistical method is rarely taught to educational researchers in graduate schools. Thus, researchers who intend to study student departure should be encouraged to receive training in these analytical techniques.

\section{Alternative Approach for Examining Differential Aid Effects}

Thus far, this chapter has reviewed and critiqued three major components of the student dropout literature: theoretical perspectives, empirical research, and methodologies. In this following section, I argue that applying the results of the general aid effects to students from different income and racial/ethnic groups is not recommended when evaluating the effects of financial aid. An alternative and more reasonable approach is to make particular assumptions about different groups' decision-making processes. In the heterogeneous approach developed in this chapter, I use the economic concepts of liquidity constraints, price elasticity, and debt aversion to illustrate why students from different income and racial/ethnic backgrounds may respond to financial aid in different ways. I also propose two hypotheses that can be tested in future research to promote a better understanding of the role financial aid plays in equalizing educational opportunities.

\section{Economic Concepts}

The heterogeneous approach developed in this chapter is based on human capital theory and supply and demand theory. In addition, it proposes using the economic concepts of liquidity constraint, price elasticity of demand, and debt aversion to illustrate how subgroup students have different economic background, and thus respond differently to financial aid.

Liquidity constraint is a form of imperfection in the capital market indicating a limit on the amount an individual can borrow or a limit on the interest rate he or she can pay. A rise in the cost of borrowing often tends to prevent individuals from fully optimizing their behavior. This market imperfection often tends to have a greater impact on students from disadvantaged socioeconomic backgrounds because access to liquidity is crucial for them and they face higher borrowing costs than do their 
counterparts with greater advantages. For example, increases in Pell grants and merit aid, which reduce net tuition, may help better reduce liquidity constraint problems for low-income students.

The price elasticity of demand is a ratio of proportionate change in quantity demanded by proportionate change in price. For example, if a $2 \%$ decrease in net tuition due to an increase in financial aid resulted in a $1 \%$ increase in enrollment, the price elasticity of demand would be equal to approximately 0.5 . A higher level of price elasticity indicates a higher level of sensitivity to changes in price. The price elasticity of demand is influenced by a variety of factors, including the proportion of income required by the product. Products requiring a larger portion of consumer income tend to have greater elasticity. In the higher education context, compared with their higher income peers, low-income students pay a larger proportion of family income for college education. Thus, they may have a relatively higher level of price elasticity and more elastic demand for higher education, while high income peers' demand is relatively inelastic. As a result, low income students tend to be more sensitive to net tuition changes through financial aid.

The third concept that helps explain the possible differential effects of financial aid is debt aversion, a reluctance to incur debt. Students from different income backgrounds may have different views of debt. Compared with their higher income counterparts, students from low-income families often have a lower threshold for risk of indebtedness. Consequently, increases in financial support through grants or merit aid can reduce their anxiety about the costs they will face. Alternatively, decreased aid and the perception of rising levels of debt will likely discourage their persistence.

\section{Hypotheses for Testing Differential Aid Effects}

Based on the economic theories and concepts and the main effect bias, I develop two testable hypotheses for a better understanding of the role of financial aid in equalizing educational opportunities.

Hypothesis I: Aid types and amounts will have varied impact on student departure based on level of family income. In other words, there is an interaction between family income and the type and amount of aid received. The rationale for this hypothesis derives from the fact that low-income students have higher levels of liquidity constraints, price elasticity, and debt aversion, and are thus more sensitive to net tuition and financial aid changes. Since loans require that students pay back the principle plus interest, and work study aid requires students to work in order to be qualified, their effects on student dropout behavior may be different from the larger Pell grants or merit aid, which reduce net tuition. It is possible that Pell grant or merit aid decreases the dropout probability among low-income students more than that of students from middle or high income families. However, the strength of the impact of loans and work-study on the student dropout decision may not be the same. 
Hypothesis II: For aid recipients, the effects of aid amounts on dropout may vary based on their race/ethnicity. The logic is similar to the income hypothesis above: minority students may be more sensitive to net tuition and financial aid changes and are also more debt-averse relative to their White counterparts. The rationale to support the test of this hypothesis is that the impact of aid may be mediated by some unobservable factors such as cultures and value differences that are distinctly related to racial/ethnic groups. Although there is no empirical research on how cultures and value may mediate aid effects on student departure, economists have found that differences do exist in economic decisions across racial and ethnic groups. For example, compared with minorities, Whites tend to exhibit less risk-averse preferences (Benjamin et al., 2007), and relative to Whites, Asian Americans are more likely to participate in tax-deferred savings account (Springstead \& Wilson, 2000). These economic studies suggest that cultural factors may contribute to racial/ethnic differences in economic decisions. Given these findings, it is reasonable to hypothesize that students from diverse racial/ethnic backgrounds may respond to financial aid changes differently. Minority students may be more sensitive to changes in need-based aid like Pell grants in their dropout process.

\section{Recommended Conceptual Model}

To develop a more inclusive conceptual framework for assessing the effects of student aid policies on reducing dropout risks, it is important to not only consider the sub-group variations, but also rethink the common assumptions underlying the evaluation of financial aid effects in higher education research. Thus, in addition to theories from psychological, sociological, organizational, and interactionalist perspectives, it is necessary to take into account human capital and supply and demand theories, along with the issues of liquidity constraints, price elasticity, and debt aversion. This conceptual model includes the outcome variable and eight major constructs for independent variables, namely student background, educational aspiration, pre-college preparation, financial factors, college experience, institutional characteristics, interaction effects, and time in college.

\section{Dependent Variable}

Student dropout is a measure of the flow of students out of higher education institutions. Three major types of departure are identified in the literature: stopout, institutional departure, and system departure. Stopout students often come back after a short period of disenrollment, institutional dropouts may transfer to other institutions; and system departures are those who leave higher education for good and whose behaviors could not be observed in stopout or institutional departure studies. Generally, stopout and institutional departure are of greater interest to institutional stakeholders, who are responsible for the policies and programs designed to 
improve student persistence within particular institutions; system departure is often the focus of research and policies at the state and national level. Considering that student dropout from higher education has been a nationwide issue for decades (Tinto, 1987, 1993), and considering the longitudinal nature of this behavior, it is appropriate to define the dependent variable as system departure during an observation period that is long enough to observe most students' graduation. A good example of the possible dataset to use is Beginning Postsecondary Students (BPS: 96/01), a national survey that tracks cohort of students who began their postsecondary education during the mid 1990s over a six-year observation period.

\section{Independent Variables}

Next I discuss the independent variables to be incorporated into this model. In general, researchers from psychological, sociological, organizational, interactionalist, and economic perspectives have identified various factors influencing student departure. These factors can be rearranged into eight clusters of variables comprising student background characteristics, educational aspirations, pre-college preparation, college experience, organizational effects, financial factors, time, and interaction effects. Because the first five clusters of variables are commonly identified in the literature, I mention them here only briefly, paying more attention to the remaining three clusters (i.e., financial factors, time, and interaction effects), which are central to the proposed model.

\section{Student Background Characteristics}

A variety of background characteristics are found to be related to student dropout and are often used as control variables. These factors are students' gender, age, race/ethnicity, family income, and parental education. It is worth noting that family income and parental education are examined separately in this model because some evidence (Paulsen \& St. John, 2002) indicates that family income is far more complex than is communicated by the aggregated socioeconomic status (SES). In the proposed model, family income will be included in the baseline model for exploring whether there are income gaps in dropout risks. It is then used to divide the sample for subgroup analyses. If found to be significant, this variable will be used in the full model as main effects and as a part of the interaction terms to examine the effects of financial aid on reducing dropout risk gaps by family income. The same process applies to the use of the race/ethnicity variable.

\section{Educational Aspiration}

In addition to student background characteristics, student educational aspiration is another important variable to be included in the conceptual model. The measure of this factor often represents the highest level of education a student plans to achieve. 


\section{Pre-College Preparation}

As measures of examining students' academic performance in high school and qualifications to graduate and go to college, high school grade point average (GPA) and college entrance examination performance are usually used to control for students' academic ability. Among them, college entrance examination performance is often measured by SAT or ACT scores. An alternative measurement is an indicator named the "merit index" (St. John et al., 2001), which quantifies the relationship between a student's college admission score and the average score for all college-bound students within the same school during the same test administration period. The authors compared the effects of SAT and the merit-aware index on within-year persistence of firstyear college students and found that this merit index predicts college persistence about as well as the SAT. Thus, in analyzing differential aid effects on student dropout risks, researchers may apply traditional indicators, such as SAT or ACT scores, or use this merit index as an alternative indicator in departure research.

\section{College Experience}

Apart from student background characteristics, educational aspirations, and precollege preparation, student experiences in college are also shown to be related to student departure from higher education. Some of the attributes are found important in predicting dropout include college GPA, major fields, academic integration, and social integration. Academic integration is a major construct in Tinto's (1975, 1993) integration model, which includes structural and normative dimensions concerning an individual's integration with the social systems of a higher education institution. Students' satisfaction with faculty and with the quality of instruction and curriculum, and academic advising are used to represent this attribute. Social integration concerns the degree of congruency between an individual and the social systems of a higher education institution. Some of the major variables examined include students' interaction with faculty and their interaction with their peers.

\section{Organizational Characteristics}

Institutional attributes are expected to be related to student departure (Tinto, 1987; Berger, 2000a, b). The most studied organizational factor in the dropout literature is institutional control, which indicates whether the institution is public vs. private.

\section{Financial Factors}

In addition to student background characteristics, educational aspirations, and precollege preparation, differential aid effect analyses should incorporate financial factors including students' perceptions about college costs and variables indicating financial aid, college price, and labor market conditions. 


\section{Perceptions About College Costs}

Some researchers (St. John et al., 1996, 2005) have argued that the reasons students choose to attend college could be considered dimensions of initial commitments, which may influence subsequent persistence. Examinations of the nexus between persistence and the influence of a set of college-choice variables indicate that two finance-related choice factors, namely choice because of low tuition and choice because of financial aid, are significant and are negatively associated with persistence. The evidence for a nexus between student choice and persistence suggests that financial-choice factors, including choosing a college because of low-tuition or financial aid, should be considered in examining student dropout behavior.

\section{Financial Aid}

Investigation of student aid effects on departure has gone through roughly five stages. Early on, the focus of study was student perceptions about aid. It was common to examine students' attitude toward whether financial aid mattered or not, rather than the actual type or amount of aid received. In the second stage, researchers adopted a rough measure indicating whether or not students received aid, regardless of type (Astin, 1975; Stampen \& Cabrera, 1986, 1988). But scholars soon found that the effects of aid may differ by aid type, thus expanding the scope of research to analyzing the impact of different aid types (Nora et al., 1996; Perna, 1998; St. John \& Starkey, 1995). This aid-type research focused chiefly on behavioral differences between aid recipients and non-recipients of a certain type of aid. This line of research helped differentiate the effects of different types of aid, such as grants, loans, and work-study, on student departure. More recently, scholars have come to realize that detailed information about financial aid would be lost if only aid types rather than aid amount variables were used. Thus, the measure of aid amount has been integrated into research models (DesJardins et al., 2002a; 2002b; Paulsen \& St. John, 2002; St. John, 1990). The aid amount research focuses on the effect of the amount of certain types of aid on student departure. Research on the timing of aid represents the newest trend in the student persistence/departure literature. Using a longitudinal approach, researchers (Chen \& DesJardins, in press; DesJardins et al., 1999; Ishitani \& DesJardins, 2003; St. John et al., 1991) have examined how the effects of aid vary over time. By incorporating the temporal characteristics of aid receipt, this group of longitudinal studies has advanced student dropout research and promoted a better understanding of financial aid effects.

The brief review of the departure research on the effects of financial aid leads us to several conclusions. First, different types of aid are found to affect students' dropout behavior differently. But the literature is not clear as to which types of aid have the greatest impact (Pascarella \& Terenzini, 2005). In most studies, grant aid is found to have a positive effect on persistence (Astin, 1975) and negative effect on departure (DesJardins et al., 1999), while in a few research (Moline, 1987; Peng 
\& Fetters, 1978), no significant relationship is discovered. For loans, Voorhees (1985) found that Federal Perkins Loans have a strong positive impact on persistence, while Peng and Fetters (1978) asserted that loans are not related to persistence. Other researchers (Astin, 1975; Hochstein \& Butler, 1983; St. John \& Starkey, 1995) have discovered that students who take out loans are less likely to persist. In the review of college impact, Pascarella and Terenzini (2005) conclude that work-study assistance generally increase the chance of persistence. But St. John and Starkey's (1995) study indicates that the amount of work study is significant and negatively associated with persistence for students from low- and middle-income families. Too much self-help could be problematic, at least for some students.

Second, only a few studies examined the differential effects of financial aid on the departure decisions for students from divergent backgrounds. In the past two decades, two important pieces of research on college access (Leslie \& Brinkman, 1987; Heller, 1997) put forward a price-demand notion illustrating that price sensitivity generally lessens as income rises in their college-going decision-making process. More recently, a few studies (Hu \& St. John, 2001; Paulsen \& St. John, 2002; Perna, 2000; St. John \& Starkey, 1995; St. John, 2003) took a major step forward by investigating the variations in aid effects in students' persistence decisions. This differential approach (St. John, 2003) examines aid effects by dividing student population into different income or racial/ethnic groups and conducting subgroup analyses. These exploratory studies found that student aid effects are not uniform, but vary by income and racial groups. For example, both grants and work-study aid were found to exert unequal influences on students with different family incomes (St. John \& Starkey, 1995). Loans even have negative effect on African-American students (Perna, 2000). Although another study found no significant difference in the effect of loans by income quartile in a sample of full-time students in the public four-year sector (Dowd, 2004), the author speculated that the failure to find differential effects may be due to the small sample of students in the upper income quartiles.

Given inconsistent findings in the literature, studies on student dropout risks to need to include aid measures that represent the amounts of each type of financial aid students receive each year. These aid measures are included in both the baseline and full model as main effects, and are also included as a part of the interaction terms in the full model when post-estimation tests are significant.

\section{Price}

Another important predictor in the proposed model is college price. Although the PriceResponse Approach was initiated early on (Astin, 1975; Murdock, 1987; Stampen \& Cabrera, 1986, 1988), there were a limited number of studies on the effects of price on student departure due to unavailability of suitable data in early years. Among the limited studies, findings indicated that students usually did respond to college tuition prices in their persistence decisions (Heller, 1997, 1999; St. John, 1990). With a few exceptions, most studies found that tuition charges are negatively associated with student persistence, even after controlling for potentially confounding variables such as student background characteristics and college experience (Pascarella \& Terenzini, 2005). 
Researchers (St. John \& Starkey, 1995) discovered that financial analyses in higher education before the 1980s assumed that student enrollment responded only to net price (usually constructed as the difference between tuition and financial aid); however, this net price approach has proved to be problematic. Students actually may respond to tuition and financial aid differently. Thus, the conceptual model proposed in this chapter proposes that, instead of using a single variable indicating net price, two separate measures of financial aid and tuition should be included to examine differential aid effects on student departure.

\section{Labor Market Conditions}

It has been argued that changes in labor market conditions may influence student demand and that these external influences have been systematically considered in previous studies (Dresch, 1975). Studies using time series data suggest that the labor market conditions can have an impact on college attendance in several ways. For example, Paulsen and Pogue (1988) found that the response of a college students' attendance to labor market changes depend on its curriculum: for a given selectivity classification, colleges with an emphasis on traditional arts and sciences had greater enrollment growth when the labor market condition was improving, while colleges with an emphasis on occupational fields had greater enrollment growth when the labor market condition was deteriorating. They also suggested that many colleges added new high-demand occupational programs and even dropped some less popular traditional arts and science programs in an apparent attempt to match more closely their curricular offering with the new patterns of student demand.

Some researchers have used employment as an indicator of the conditions of the labor market and have examined the relationship between employment and departure. In Pascarella and Terenzini's (1991) review of the literature, part-time employment on campus is concluded to have a positive impact on year-to-year persistence. DesJardins et al.'s (1999) study finds that on-campus employment other than work-study lowers the risk of stopping out. Some researchers have also investigated the effects of hours of employment on student dropout behavior (Iwai \& Churchill, 1982; Terenzini et al., 1996), and found that dropouts tended to work longer hours than those who persisted. Thus, to control for American labor market conditions, this proposed conceptual model includes an indictor that measures students' employment on and off campus.

\section{Time in College}

Undergraduate students experience a series of changes and transitions that influence their growth from freshmen year to graduation (Astin, 1993). From a theoretical point of view, Tinto (1993) argued that, "a general theory of student departure, if it is to be fully explanatory, must be able to account for the latter (long-term) as well as the former (short-term) mode of student departure" (p. 88). 
Although it has long been acknowledged that student departure is a longitudinal process (Spady, 1970; Tinto, 1975), studies taking time into account have appeared only recently. Some empirical evidence has been found to support the longitudinal investigation of student departure. Traditionally, the first year of college, especially the first semester, is a critical period in a student's academic career (Tinto, 1993); sophomores, juniors, and seniors are found to be much more likely to persist than freshmen (Tinto, 1987, 1993). However, scholars have recently shifted their attention from first year students, revealing that departure is also a problem in the years after some initial success in college (Nora et al., 2005). In addition, studies using longitudinal methods have found that the strength and direction of the factors related to student departure such as financial aid, may change over time (Chen \& DesJardins, in press; DesJardins et al., 1999; Ishitani \& DesJardins, 2003).

The temporal analysis unit in event history modeling depends on the availability of data. In higher education studies, most longitudinal data are collected on a yearly basis; thus, information about the outcome and independent variables are often only available for each academic year, instead of each semester or month. Consistent with most studies (Chen \& DesJardins, in press; DesJardins et al., 1999; Ishitani \& DesJardins, 2003), this conceptual model suggests using the academic year as the temporal analysis unit.

\section{Interaction Effects}

Most prior research on student departure ignored interaction effects, thereby bringing a "main effects" bias to their results. As Singer and Willett (2003) noted, one of the many possible misspecifications of a statistical model is the failure to take into consideration significant interaction effects between covariates. Almost every investigation of human behavior suggests that predictors' effects may differ depending on an individual's background and culture. However, most of the models in the student departure research presented in substantive journals has emphasized main effects and ignored any possible interactions. Only a few studies have compared the effects of tuition or financial aid on student departure/persistence for different income groups by running separate regressions. However, as Chen and DesJardins (in press) point out, these studies are still limited for not considering the interaction effect test. In order to avoid a "main effects" bias, researchers need to incorporate a formal statistical test for the difference between the coefficients for different groups (Jaccard, 2001).

As discussed above, failure to explore interaction effects is one of the major methodological deficiencies in student departure research. Without knowing whether and how some intervening/policy factors may influence students from divergent backgrounds, it is difficult to help policymakers target their interventions or policies to reduce the departure gap across various student groups.

Nevertheless, a purely data-driven search for interaction effects is not recommended. Based on the findings from literature and the hypotheses proposed, three sets of interactions are suggested for future research on financial aid and student 
departure. First, in order to examine what types and amounts of aid are relatively more effective in reducing the observed dropout gap by income level, a series of interactions between income and all types of financial aid are needed. Second, a similar set of interaction terms must also be included to test the interactions between race/ ethnicity and financial aid. Third, since the effects of financial aid may vary over time, it is necessary to include interactions between student year in college and financial aid.

\section{Model Specification Issues}

Before using the proposed model for student dropout research, three issues must be considered in model specification: multicollinearity, selection bias, and complex survey design characteristics. Multicollinearity occurs when two or more predicting variables are highly correlated, which means they essentially measure the same construct and contain redundant information. Severe multicollinearity leads to larger standard errors and unstable estimated coefficients (Devore \& Peck, 2001). When using the proposed model, researchers need to perform correlation tests test-including calculation of tolerance values or variance inflation factors - on the independent variables to avoid potential multicollinearity problems.

The second model specification issue is related to selection bias. As some scholars have observed (DesJardins et al., 2002b; Weiler \& Pierro, 1988), many college choice and departure studies have incorporated some additional factors, such as whether a student delays entry, attends college full or part time, and lives in an oncampus residence hall or not into the models. The association found in some of the studies between full-time attendance and persistence, however, "may have arisen because the students selecting those choices had more of unmeasured factors that influenced both, not because of any true causal relationship between attendance status and persistence" (Weiler \& Pierro, 1988, p. 264). Individual students with particular measured or unmeasured characteristics choose their program status nonrandomly, which implies that the significant effect does not actually reflect a true causal influence of the program status on persistence. Some scholars (DesJardins et al., 2002b; Weiler \& Pierro, 1988) cautioned against using these kinds of factors in investigating student departure. Other researchers (Alon, 2005; DesJardins, 2005) also pointed out that it is important to control for the relationship between aid eligibility and college outcomes, because the effect of aid received may be due to non-random selection into aid eligibility. Therefore, adjusting for self-selection in educational research is an area that requires much more attention and study. A few methods to deal with selection issues include propensity score matching methods and regression discontinuity analysis, etc. These methods combined with longitudinal analytic techniques could reduce selection bias in analyzing the effects of financial aid and push this line of research even further.

The third issue is associated with the analysis of survey data. Large-scale secondary data available from the National Center for Education Statistics (NCES) are often 
designed with complex survey design characteristics, including unequal probabilities of selection, stratification, and clustering (NCES, 2002). It is important to take these characteristics into account when analyzing the data because neglecting them often leads to smaller standard errors estimates and p-values, in turn falsely producing significant coefficients (Thomas \& Heck, 2001). Therefore, when using large-scale secondary datasets to study student dropout risks, researchers should utilize corresponding weight, strata and cluster variables to account for the complex survey design.

\section{Suggested Approach for Analysis}

\section{Statistical Methods}

Static analytic methods, such as logistic regression, etc., are appropriate and widely used for cross-sectional data. But as I argued in prior sections that student persistence/ dropout is a temporal process, it is proper to use longitudinal data and longitudinal methods. One of these methods - the event history modeling (or survival analysis) fits well for the study of student dropout risks. First, this analytic technique can deal with observations that are censored, which is a missing data problem that traditional statistical methods are not designed to remedy. Second, event history methods are able to incorporate variables whose values change over time. For example, in student dropout studies, the types and amounts of financial aid a student receives may change from one year to another. But traditional techniques are not easily adapted to take these time-varying covariates into consideration. Event history methods are, however, explicitly designed to deal with time-dependent covariates (DesJardins, 2003).

Originally developed by biostatisticians, event history analysis has often been applied in the medical, economic, and sociological fields of research (Allison, 1995), and has only been used to study the timing of educational events more recently (Willett \& Singer, 1991). It is now a preferred analytical tool for investigating how multi-faceted factors influence student dropout over time (DesJardins, 2003). For this alternative framework specifically, this analytic method allows us to determine whether certain types and amounts of financial aid have effects that change over time, and how other various factors are related to student dropout risks at different points over a student's academic career.

There are two major types of event history models, depending on how the time-ofevent is measured (Yamaguchi, 1991). One type is called "continuous-time methods," such as Cox's method, which assumes that the time of the outcome event is precisely known. In the fields of medical and engineering research, continuous-time event history methods are often used because the event times are often precisely recorded. The other type of event history methods is "discrete-time methods," in which time is often measured in discrete units of time. For example, in educational studies, time is often measured in semesters or years, so naturally discrete-time event history methods are more appropriate. The second consideration concerns the number of 
ties in the data. Events have ties when two or more subjects in the sample have the event at the same time (Singer \& Willett, 2003). The use of Cox's method for proportional hazards models would lead to a serious bias in estimates if the data had too many ties. Discrete-time models are recommended as an appropriate approach for handling ties without introducing bias (Yamaguchi, 1991; Singer \& Willett, 2003). Given the nature of the time measured and the existence of many ties in most data for educational research, this proposed framework uses discretetime event history methods.

\section{Analytic Approach}

Based on the conceptual model discussed above, a three-step approach is recommended for data analysis. The first step is to fit a baseline model that uses the whole sample and incorporates all of the independent variables except interaction effects. Following is the equation for this baseline model

$$
\text { Logit } h\left(t_{i j}\right)=\left[\alpha_{1} D_{1 i j}+\alpha_{2} D_{2 i j}+\ldots+\alpha_{J} D_{J i j}\right]+\left[\beta_{1} X_{1 i j}+\beta_{2} X_{2 i j}+\ldots+\beta_{p} X_{p i j}\right]
$$

where the risk of student dropout is a logit function of two sets of predictors: time (Ds) and Xs (other independent variables). Xs may be time-invariant variables such as student race/ethnicity, SAT score, high school GPA, or institutional control, but may also include time-varying regressors such as student aid (the amount of aid a student receives for Pell grant, loans, or work study aid in each academic year). Fitting the baseline model facilitates a general understanding of the income and racial/ethnic differences in dropout risks as well as the effects of financial aid for the sample as a whole.

The second step is to conduct subgroup analyses, which means running a separate analysis on each income and racial/ethnic group. For example, if we want to do subgroup analyses by income, we need to divide the whole sample into sub-samples that represent students from different income levels. Once the samples are divided, we use the baseline model and conduct event history analysis on each income-group sample. The income variables need to be first removed from the baseline model, however, when conducting subgroup analyses by family income. The procedure for subgroup analyses by race/ethnicity is the same. The purpose of subgroup analyses is to detect whether there are differences in aid effects by income and race/ethnicity. Of course, dividing the data into subgroups often reduces studies' power to detect differential aid effects because the sample sizes are reduced. In addition, whether or not aid effects are significantly different should be determined through formal tests of interaction effects. Thus, this subgroup analyses step is exploratory in nature, and additional steps will need to be taken.

The third stage of analysis involves a series of tests for interaction effects using the whole sample and examining the variation of income and racial/ethnic differences in dropout risks as a function of financial aid. To avoid the "main effect" bias discussed earlier, two sets of interaction terms (income and aid; race/ethnicity and 
aid) are added to the baseline model. Each set of interactions is incorporated into the baseline model independently, and each model with a group of interaction terms is then compared with the baseline model using a post-estimation test (e.g., -2 loglikelihood ratio test or Wald test). The purpose of performing post-estimation tests is to check whether the addition of interaction terms improves the model fit to the sample data. If a post-estimation test suggests that a specific set of interaction terms are significantly different from zero, then we need to include the interaction terms because the model with interaction terms provides for a better fit than the baseline model. After all these interaction effect tests, we may then fit a full model that simultaneously includes all significant interaction terms identified through the prior significance tests.

\section{Interpretation of the Interaction Effects}

Because interaction effects are often difficult to conceptualize, the interpretation of the results deserves careful attention. While many articles on logistic regression introduce general strategies for testing interactions, few provide concrete tools for understanding and interpreting the coefficients for the interaction terms. A good approach to interpreting the results of the interaction effects is to calculate the predicted probability of the outcome for each income and racial/ethnic group, and then present the results in tables or graphs (Jaccard, 2001). Refer to Chen and DesJardins' (in press) article for an example of how to interpret interaction effects using this approach.

\section{Conclusion}

With persistent socioeconomic and racial/ethnic gaps in college student dropout risks, and the dramatic shift in financial aid policies, there is an urgent need for understanding how financial aid can influence these inequalities in higher education in specific ways. This chapter provides an alternative perspective that can be used to further explore the differential aid effects on student dropout risks. Currently, most studies on student dropout from higher education tend to assume that financial aid exerts a uniform effect on students, ignoring the fact that the student body is heterogeneous and may respond differently according to income and racial/ethnic background. Specifically, these studies are limited in at least two ways. Failing to address variations in response to financial aid among different student groups, they do not have sufficient explanatory power to account for the ways in which finance influences students' behavior in different contexts. In addition, neglecting the longitudinal nature of student dropout may lead to a failure in accounting for the possible time-varying effects of financial aid.

In this chapter, I argue that investigations of financial aid effects on student dropout risks can be conducted using a heterogeneous approach that considers various 
levels of student responsiveness to financial aid changes over time. First, it includes an understanding of how student subgroups respond to financial aid differently; second, it considers whether these differences are significant enough to narrow student dropout risk gaps in a longitudinal process.

As noted earlier, some scholars' research (e.g., Heller, 1997; St. John, 2003) is an important step forward in explicitly examining financial aid effects by different student groups. The alternative model and approach presented in this chapter is an attempt to deepen and expand St. John's (2003) "differential approach" and the notion of price demand explored by Leslie and Brinkman (1987) and Heller (1997). This heterogeneous approach provides additional power to explain how students from divergent social backgrounds may behave differently in their dropout decision. It also allows the examination of differential aid effects on dropout risks over various points in the time of students' academic careers. In addition, this approach may be extended to studies on college success gaps, as well as policy interventions that target at narrowing inequality in higher education. It should be noted, however, that this heterogeneous approach is meant to provide one means for understanding the effects of financial aid on student dropout risks. I hope that scholars with an interest in this area will look for more ways to investigate how financial aid influences student departure behavior.

Estimating the effects of financial aid on student persistence in and dropout from higher education is by no means straightforward (Heller, 2003; Pascarella \& Terenzini, 2005). The combination of amounts, forms, and sources of financial aid that students receive can be very complex, and the funding levels and aid eligibility rules can change frequently (Pascarella \& Terenzini, 2005), presenting formidable challenges for a thorough investigation of the role financial aid plays in reducing dropout risk gaps. However, with continual effort by scholars from various disciplines, more and more cutting-edge studies will further illuminate the divergent effects of financial aid, which will help policy-makers to target their policies for promoting equality in American higher education.

Acknowledgements I wish to thank Edward St. John for his insightful comments and suggestions during the writing of this chapter. I am also grateful to Stephen DesJardins, Michael Paulsen, and Shouping $\mathrm{Hu}$ for their valuable feedback on an earlier draft of this manuscript. The views expressed in this chapter are that of the author, and any remaining errors are the author's responsibility.

\section{References}

Allison, P. D. (1995). Survival Analysis Using the SAS System: A Practical Guide. Cary, NC: SAS Institute.

Alon, S. (2005). Model mis-specification in assessing the impact of financial aid on academic outcomes. Research in Higher Education, 46(1), 109-125.

Anderson, M. S., \& Hearn, J. C. (1992). Equity issues in higher education outcomes. In W. E. Becker \& D. R. Lewis (Eds.), The Economics of American Higher Education (pp. 301-334). Boston, MA: Kluwer. 
Astin, A. W. (1975). Preventing Students from Dropping Out (1st ed.). San Francisco, CA: Jossey-Bass.

Astin, A. W. (1993). What Matters in College? Four Critical Years Revisited. San Francisco, CA: Jossey-Bass.

Bean, J. P. (1980). Dropouts and turnover: The synthesis and test of a causal model of student attrition. Research in Higher Education, 12(2), 155-187.

Bean, J. P. (1983). The application of a model of turnover in work organizations to the student attrition process. Review of Higher Education, 6(2), 129-148.

Bean, J., \& Eaton, S. B. (2000). A psychological model of college student retention. In J. M. Braxton (Ed.), Reworking the Student Departure Puzzle (pp. 48-62). Nashville, TN: Vanderbilt University Press.

Becker, G. S. (1964). Human Capital: A Theoretical and Empirical Analysis with Special Reference to Education. New York: National Bureau of Economic Research.

Becker, R. T., \& Nelder, J. A. (1978). The GLIM System: General Linear Interactive Modeling (3rd ed.). Oxford: Numerical Algorithms Group.

Benjamin, D. J., Choi, J. J., \& Strickland, A. J. (2007). Social Identity and Preferences (No. 07-621). Ann Arbor, MI: University of Michigan.

Berger, J. B. (2000a). Organizational behavior at colleges and student outcomes: A new perspective on college impact. Review of Higher Education, 23(2), 177-198.

Berger, J. B. (2000b). Optimizing capital, social reproduction, and undergraduate persistence: A sociological perspective. In J. M. Braxton (Ed.), Reworking the Student Departure Puzzle (pp. 95-126). Nashville, TN: Vanderbilt University Press.

Berger, J. B., \& Braxton, J. M. (1998). Revising Tinto's Interactionalist theory of student departure through theory elaboration: Examining the role of organizational attributes in the persistence process. Research in Higher Education, 39(2), 103-119.

Berger, J. B., \& Milem, J. F. (1999). The role of student involvement and perceptions of integration in a causal model of student persistence. Research in Higher Education, 40(6), 641-664.

Berger, J. B., \& Milem, J. F. (2000). Organizational behavior in higher education and student outcomes. In J. Smart (Ed.), Higher Education: Handbook of Theory and Research (Vol. 15, pp. 268-338). New York: Agathon.

Berger, M. C. (1992). Private non-monetary returns. In W. E. Becker \& D. R. Lewis (Eds.), The Economics of American Higher Education. Boston, MA: Kluwer.

Bourdieu, P. (1973). Cultural reproduction and social reproduction. In R. Brown (Ed.), Knowledge, Education and Cultural Change (pp. 487-510). London: Tavistock.

Bourdieu, P. (1977). Outline of a Theory of Practice. Cambridge: Cambridge University Press.

Bowen, H. R. (1997). Investment in Learning: The Individual and Social Value of American Higher Education. Baltimore, MD: Johns Hopkins University Press.

Braxton, J. M. (2000). Reworking the Student Departure Puzzle (1st ed.). Nashville, TN: Vanderbilt University Press

Braxton, J. M., \& Hirschy, A. S. (2005). Theoretical developments in the study of college student departure. In A. Seidman (Ed.), College Student Retention: Formula for Student Success. Westport, CT: American Council on Education/Praeger.

Braxton, J. M., Hirschy, A. S., \& McClendon, S. A. (2004). Understanding and reducing college student departure. In A. J. Kezar (Ed.), Ashe-Eric Higher Education Report V (Vol. 30, No. 3). San Francisco, CA: Wiley.

Cabrera, A. F., Stampen, J. O., \& Hansen, W. L. (1990). Exploring the effects of ability to pay on persistence in college. Review of Higher Education, 13(3), 303-336.

Cabrera, A. F., Castaneda, M. B., Nora, A., \& Hengstler, D. (1992a). The convergence between two theories of college persistence. Journal of Higher Education, 63(2), 143-164.

Cabrera, A. F., Nora, A., \& Castaneda, M. B. (1992b). The role of finances in the persistence process: A structural model. Research in Higher Education, 33(5), 571-594.

Chen, R., \& DesJardins, S. L. (2008). Exploring the effects of financial aid on the gap in student dropout risks by family income. Research in Higher Education, 49(1), 1-18. 
Clark, B. (1960). The "cooling out" function in higher education. American Journal of Sociology, 65, 569-576.

College Board (2005a). Trends in Student Aid (p. v). Washington, DC.

College Board (2005b). Trends in College Pricing (p. v). Washington, DC.

DesJardins, S. L. (2003). Event history methods: Conceptual issues and an application to student departure from college. Higher Education: Handbook of Theory and Research, 18, 421-471.

DesJardins, S. L. (2005). Investigating the efficacy of using selection modeling in research of the Gates Millennium Scholars Program. Paper Presented to Gates Millennium Scholars Research Advisory Council.

DesJardins, S. L., \& Toutkoushian, R. K. (2005) Are students really rational? The development of rational thought and its application to student choice. Higher Education: Handbook of Theory and Research, 20, 191-240.

DesJardins, S. L., Ahlburg, D. A., \& McCall, B. P. (1999). An event history model of student departure. Economics of Education Review, 18(3), 375-390.

DesJardins, S. L., Ahlburg, D. A., \& McCall, B. P. (2002a). Simulating the longitudinal effects of changes in financial aid on student departure from college. Journal of Human Resources, 37(3), 653-679.

DesJardins, S. L., McCall, B. P., Ahlburg, D. A., \& Moye, M. J. (2002b). Adding a timing light to the "tool box." Research in Higher Education, 43(1), 83-114.

Devore, J. L., \& Peck, R. (2001). Statistics: The Exploration and Analysis of Data. Pacific Grove, CA: Duxbury.

Diggle, P. J., Liang, K. Y., \& Zeger, S. L. (1994). Analysis of Longitudinal Data. Oxford: Clarendon.

Dowd, A. C. (2004). Income and financial aid effects on persistence and degree attainment in public colleges. Educational Policy Analysis Archives, 12(21).

Dresch, S. P. (1975). A critique of planning models for postsecondary education: Current feasibility, potential relevance, and a prospectus for future research. Journal of Higher Education, 46, 246-286.

Duncan, O., Featherman, D., \& Duncan, B. (1972). Socioeconomic Background and Achievement. New York: Seminar.

Durkheim, E. (1951). Suicide: A Study in Sociology. New York: Free Press.

Elkins, S. A., Braxton, J. M., \& James, G. W. (2000). Tinto's separation stage and Its Influence on first-semester college student persistence. Research in Higher Education, 41(2), 251-268.

Featherman, D., \& Hauser, R. (1978). Opportunity and Change. New York: Academic.

Heibrun, A. (1965). Personality factors in college dropout. Journal of Applied Psychology, 49(1), $1-7$.

Heller, D. (2003). Review of NCES research on financial aid and college preparation. Report Prepared for the Advisory Committee on Student Financial Assistance. http://www.ed.gov/ about/bdscomm/list/acsfa/Heller_BeckerFinalReports.pdf.

Heller, D. E. (1997). Student price response in higher education: An update to Leslie and Brinkman. Journal of Higher Education, 68, 624-659.

Heller, D. E. (1999). The effects of tuition and state financial aid on public college enrollment. Review of Higher Education, 23(1), 65-89.

Heller, D. E., \& Marin, P. (Eds.) (2002). Who Should We help? The Negative Social Consequences of Merit Scholarships. Cambridge, MA: The Civil Rights Project at Harvard University.

Hochstein, S. K., \& Butler, R. R. (1983). The effects of the composition of a financial aids package on student retention. Journal of Student Financial Aid, 13, 21-26.

Hu, S., \& St. John, E. P. (2001). Student persistence in a public higher education system: Understanding racial and ethnic differences. Journal of Higher Education, 72(3), 265-286.

Ishitani, T. T., \& DesJardins, S. L. (2003). A longitudinal investigation of dropout from college in the United States. Journal of College Student Retention, 4(2), 173-201.

Iwai, S. I., \& Churchill, W. D. (1982). College attrition and the financial support systems of students. Research in Higher Education, 17(2), 105-113.

Jaccard, J. (2001). Interaction Effects in Logistic Regression. Thousand Oaks, CA: Sage. 
Kaltenbaugh, L.S., St. John, E. P., \& Starkey, J. B. (1999). What difference does tuition make? An analysis of ethnic differences in persistence. Journal of Student Financial Aid, 29(2), 21-23.

Leppel, K. (2002). Similarities and differences in the college persistence of men and women. Review of Higher Education, 25(4), 433-450.

Leslie, L. L., \& Brinkman, P. T. (1987). Student price response in higher education: The student demand studies. Journal of Higher Education, 58(2), 181-204.

McCreight, K., \& LeMay, M. (1982). A longitudinal study of the achievement and persistence of students who received basic educational opportunity grants. Journal of Student Financial Aid, 12(1), 11-15.

McPherson, M., \& Schapiro, M. O. (1998). The blurring line between merit and need in financial aid. Change, 34(2), 38-46.

Milem, J. F., \& Berger, J. B. (1997). A modified model of college student persistence: Exploring the relationship between Astin's theory of involvement and Tinto's theory of student departure. Journal of College Student Development, 38(4), 387-400.

Moline, A. E. (1987). Financial aid and student persistence: An application of causal modeling. Research in Higher Education, 26(2), 130-147.

Murdock, T. A. (1987). It isn't just money: The effects of financial aid on student persistence. Review of Higher Education, 11(1), 75-101.

The National Center for Education Statistics (2002). NCES Statistical Standards. Washington DC: US Department of Education, Institute of Educational Sciences. http://nces.ed.gov/StatProg/ 2002/std5_2.asp.

The National Center for Education Statistics (2003). Descriptive summary of 1995-96 beginning postsecondary students: Six years later. NCES, Statistical Analysis Report 2003-151. Washington DC: US Department of Education, Institute of Educational Sciences.

Nettles, M. T., \& Perna, L. W. (1997). The African American Education Data Book: Higher and Adult Education (Vol. 1). Fairfax, VA: Frederick D. Patterson Research Institute.

Nora, A. (1987). Determinants of retention among Chicago college students: A structural model. Research in Higher Education, 26(1), 31-59.

Nora, A., \& Cabrera, A. F. (1993). The construct validity of institutional commitment: A confirmatory factor analysis, Research in Higher Education, 34, 243-251.

Nora, A., Cabrera, A. F., Hagedorn, L. S., \& Pascarella, E. T. (1996). Differential impacts of academic and social experiences on college-related behavioral outcomes across different ethnic and gender groups at four-year institutions. Research in Higher Education, 37(4), 427-451.

Nora, A., Barlow, E., \& Crisp, G. (2005). Student persistence and degree attainment beyond the first year in college: The need for research. In A. Seidman (Ed.), College Student Retention: Formula for Student Success (pp. 129-154). Westport, CT: American Council on Education.

Pantages, T. J., \& Creedon, C. F. (1978). Studies of college attrition: 1950-1975. Review of Educational Research, 48, 49-101.

Park, K. H. (1996). Educational expansion and educational inequality on income distribution. Economics of Education Review, 15(1), 51-58.

Pascarella, E. T., \& Chapman, D. W. (1983). A multi-institutional, path analytic validation of Tinto's model of college withdrawal. American Educational Research Journal, 20(1), 87-102.

Pascarella, E. T., \& Terenzini, P. T. (1980). Predicting persistence and voluntary dropout decisions from a theoretical model. Journal of Higher Education, 51, 60-75.

Pascarella, E. T., \& Terenzini, P. T. (1991). How College Affects Students: Findings and Insights from Twenty Years of Research. San Francisco, CA: Jossey-Bass.

Pascarella, E. T., \& Terenzini, P. T. (2005). How College Affects Students: A Third Decade of Research. San Francisco, CA: Jossey-Bass.

Paulsen, M. B. (1998) Recent Research on the economics of attending college: Returns on investment and responsiveness to price. Research in Higher Education, 39(4), 471-489.

Paulsen, M. B. (2001) The economics of human capital and investment in higher education. In M. B. Paulsen \& J. C. Smart (Ed.), The Finance of Higher Education: Theory, Research, Policy, and Practice. New York: Agathon. 
Paulsen, M. B., \& Pogue, T. (1988). Higher education enrollment: The interaction of labor market conditions, curriculum, and selectivity. Economics of Education Review, 7(3), 275-290.

Paulsen, M. B., \& St. John, E. P. (2002). Social class and college costs: Examining the financial nexus between college choice and persistence. Journal of Higher Education, 73(2), 189-236.

Peng, S. S., \& Fetters, W. B. (1978). Variables involved in withdrawal during the first two years of college: Preliminary findings from The National Longitudinal Study of the High School Class of 1972. American Educational Research Journal, 15(3), 361-372.

Perna, L. W. (1998). The contribution of financial aid to undergraduate persistence. Journal of Student Financial Aid, 28(3), 25-40.

Perna, L. W. (2000). Differences in the decision to attend college among African Americans, Hispanics, and Whites. Journal of Higher Education, 71(2), 117-141.

Perna, L. W. (2003). The private benefits of higher education: An examination of the earnings premium. Research in Higher Education, 44(4), 451-472.

Price, J. L. (1977). The Study of Turnover. Ames, IA: Iowa State University Press. Psacharopoulos, G. (1987). Economics of education: Research and studies. In Advances in Education (1st ed., pp. xvi, 482). Oxford/New York: Pergamon.

Rendon, L. I., Jalomo, R. E., \& Nora, A. (2000). Theoretical considerations in the study of minority student retention in higher education. In J. M. Braxton (Ed.), Reworking the Student Departure Puzzle (pp. 127-153). Nashville, TN: Vanderbilt University Press.

Radner, R., \& Miller, L. S. (1975). Demand and supply in U.S. higher education. Report Prepared for the Carnegie Commission on Higher Education. Berkeley, CA: McGraw-Hill.

Rootman, I. (1972). Voluntary withdrawal from a total adult socializing organziation: A model. Sociology of Education, 45, 258-270.

Rossmann, J., \& Kirk, B. (1970). Factors related to persistence and withdrawal among university students. Journal of Counseling Psychology, 17(1), 56-62.

Schultz, T. W. (1961). Investment in human capital. The American Economic Review, 1(2), 1-17.

Singer, J. D., \& Willett, J. B. (2003). Applied Longitudinal Data Analysis: Modeling Change and Event Occurrence. Oxford/New York: Oxford University Press.

Slaugher, S., \& Leslie, L. (1997) Academic capitalism: politics, policies, and the entrepreneurial University. Baltimore: Johns Hopkins Press.

Spady, W. G. (1970). Dropouts from higher education: An interdisciplinary review and synthesis. Interchange, 1, 64-85.

Springstead, G. R., \& Wilson, T. M. (2000). Participation in voluntary individual savings accounts: An analysis of IRAs, 401(k)s, and TSP. Social Security Bulletin, 63(1), 34-39.

St. John, E. P. (1990). Price response in persistence decisions: An analysis of the high school and beyond senior cohort. Research in Higher Education, 31(4), 387-403.

St. John, E. P. (1991). The impact of student financial aid: A review of recent research. Journal of Student Financial Aid, 21, 18-32.

St. John, E. P. (2003). Refinancing the College Dream: Access, Equal Opportunity, and Justice for Taxpayers. Baltimore, MD: John Hopkins University Press.

St. John, E. P., \& Starkey, J. B. (1995). An alternative to net price: Assessing the Influence of prices and subsidies on within-year persistence. Journal of Higher Education, 66(2), 156-186.

St. John, E. P., Kirshstein, R., \& Noell, J. (1991). The Effects of student financial aid on persistence: A sequential analysis. Review of Higher Education, 14(3), 383-406.

St. John, E. P., Paulsen, M. B., \& Starkey, J. B. (1996). The nexus between college choice and persistence. Research in Higher Education, 37(2), 175-220.

St. John, E. P., Cabrera, A. F., Nora, A., \& Asker, E. H. (2000). Economic influences on persistence reconsidered: How can finance research inform the reconceptualization of persistence models? In J. M. Braxton (Ed.), Reworking the Student Departure Puzzle (pp. 29-47). Nashville, TN: Vanderbilt University Press.

St. John, E. P., Hu, S., Simmons, A. B., \& Musoba, G. D. (2001). Aptitude vs. merit: What matters in persistence. Review of Higher Education, 24(2), 131-152. 
St. John, E. P., Paulsen, M. B., \& Carter, D. F. (2005). Diversity, college costs, and postsecondary opportunity: An examination of the financial nexus between college choice and persistence for African Americans and Whites. Journal of Higher Education, 76(5), 545-569.

Stampen, J. O., \& Cabrera, A. F. (1986). Exploring the effects of student aid on attrition. Journal of Student Financial Aid, 16(2), 28-40.

Stampen, J. O., \& Cabrera, A. F. (1988). The targeting and packaging of student aid and its effect on attrition. Economics of Education Review, 7(1), 29-46.

Summerskills, J. (1962). Dropouts from college. In N. Sandford (Ed.), The American College (pp. 627-655). New York: Wiley.

Terenzini, P. T., Springer, L., Yaeger, P. M., Pascarella, E. \& Nora, A. (1996). First- generation college students: Characteristics, experiences, and cognitive development. Research in Higher Education, 37(1), 1-22.

Thomas, S. L., \& Heck, R.H (2001). Analysis of large-scale secondary data in higher education research: Potential perils associated with complex sampling designs. Research in Higher Education, 42(5), 517-540.

Tinto, V. (1975). Dropout from higher education: A theoretical synthesis of recent research. Review of Educational Research, 45(1), 89-125.

Tinto, V. (1982). Limits of theory and practice in student attrition. Journal of Higher Education, 53(6), 687-700.

Tinto, V. (1987). Leaving College: Rethinking the Causes and Cures of Student Attrition. Chicago, IL: University of Chicago Press.

Tinto, V. (1992). Student attrition and retention. In B. R. Clark \& G. R. Neave (Eds.), The Encyclopedia of Higher Education (1st ed., pp. 1697-1709). Oxford/Tarrytown, NY: Pergamon.

Tinto, V. (1993). Leaving College: Rethinking the Causes and Cures of Student Attrition (2nd ed.). Chicago, IL: University of Chicago Press.

Tinto, V. (1997). Classrooms as communities: Exploring the educational character of student persistence. Journal of Higher Education, 68(6), 599-623.

Voorhees, R. A. (1985). Student finances and campus-based financial aid: A structural model analysis of the persistence of high need freshmen. Research in Higher Education, 22(1), 65-92.

Walpole, M. (2003). Socioeconomic status and college: How SES affects college experiences and outcomes. Review of Higher Education, 27(1), 45-73.

Weiler, W. C. (1987). An application of the nested multinomial logit model to enrollment choice behavior. Research in Higher Education, 27(3), 271-282.

Weiler, W. C., \& Pierro, D. J. (1988). Selection bias and the analysis of persistence of part-time undergraduate students Research in Higher Education, 29(3), 261-272.

Willett, J. B., \& Singer, J. D. (1991). From whether to when: New methods for studying student dropout and teacher attrition. Review of Educational Research, 61(4), 407-450.

Yamaguchi, K. (1991). Event History Analysis. Newbury Park, CA: Sage. 